\title{
Bank Financing and Firms Performance in Sub-Saharan Africa: Evidence of Cameroon and Senegal
}

\author{
Agbemebia Akitan $^{1} \&$ Seydi Ababacar Dieng ${ }^{1}$ \\ ${ }^{1}$ Laboratory of Economic and Monetary research (LAREM), University Cheikh Anta Diop of Dakar, Senegal \\ Correspondence: Agbemebia Akitan, Laboratory of Economic and Monetary research (LAREM), University \\ Cheikh Anta Diop of Dakar, Senegal. E-mail: a.akitan@outlook.com
}

Received: February 27, 2020

Accepted: March 21, 2020

Online Published: April 12, 2020

doi:10.5539/ijef.v12n5p42

URL: https://doi.org/10.5539/ijef.v12n5p42

\begin{abstract}
Using survey data, the aim of this paper is to analyze the impact of bank financing on firms performance both in Cameroon and Senegal. Performance is measured in terms of sales growth. Our methodology is based on an analysis of variance to test if access to credit leads to a difference in performance and on econometric modeling. The main estimation result is that bank financing has a negative impact on firms performance. This result is explained by the credit rationing and the lack of relational behavior on the credit market. Our findings suggest the establishment of a close bank-enterprise relationship in the common quest to promote economic growth.
\end{abstract}

Keywords: bank financing, firms, performance, Cameroon, Senegal

JEL Classifications: C33, D22, L22, O11, O55.

\section{Introduction}

Firm's access to finance has been one of the major issues for the development of a dynamic private sector in Sub-Saharan Africa (SSA) over the past decades. Studies carried out in this area highlight a difficult access to credit for enterprises, particularly for small and medium-sized enterprises (SMEs), victims of credit rationing and bank mistrust (Aryeetey, 1998; Kauffmann, 2005; Lefilleur, 2008; Seck, 2014) (Note 1). The general results from the World Bank's Enterprise Surveys (Cameroon, 2009; Senegal, 2014) confirm these findings in the sense that access to finance is perceived as the main business environment obstacles in SSA.

Widely recognized and shared that the private sector is a powerful lever for a country's economic development, the plea to improve firms' access to finance has been heard by policy makers who, supported by the donor community, have embarked on reforms to improve the business environment and conduct public policies to promote entrepreneurship. Among the institutional measures to assist and support business financing, we can highlight the advent of a ministry responsible for the promotion and development of SMEs (2001 in Senegal; 2004 in Cameroon). A business environment that is ripe for making access to credit less constraining is considered necessary for the emergence of a successful private sector, promote wealth creation and meet the growth challenge. However, these works and measures taken to remove obstacles to access the finance rhyme with a gap in the literature on the efficiency of credit granted to firms in terms of performance, beyond the obvious.

Given the business lifecycle, bank credit is important due to the renewed operating and investment needs during the year. It is proving to be a means of supporting business activity and improve productivity because the role of the banking sector is to promote productive investment and support business activity (Chekili \& Saidane, 1995). According to Schumpeter (1911), the credit supply is the key to economic development. Without credit, there can be no innovation or possible progress in terms of a new productive dynamic. This is, we could say, the main part of Schumpeter's contribution, which shows that the credit created by the banker and made available to the entrepreneur is the basis for capital accumulation through innovative projects. In this respect, "credit is productive" as long as it allows a new and better combination of production factors and ensures an increase in the value produced.

Performance then arises from the productive dynamics triggered by productive investment thanks to the intervention of banks. In this perspective, it has been shown that debt has a positive impact on firms performance (Modigliani \& Miller, 1963). However, empirically, the few studies listed that examine specifically the 
relationship between bank financing and firm performance are contradictory in their results.

On the one hand, the research conducted in various contexts by Sabarwal and Terrel (2009) in Latin American countries, Jõeveer et al. (2006) in Europe, Bardasi et al. (2011) in developing regions and Djimasra et al. (2013) in Chad support the thesis that bank credit has a positive and significant impact on firm performance. On the other hand, the investigations carried out by Becchetti and Trovato (2002), Belouard and Seder (2009) and Tioumagneng (2011) reveal, in contrast, a negative relationship between the financing contracted by firms and their performance. Here we see the case where corporate indebtedness to banks can be "performance-destroying".

Nonetheless, these divergent findings are less discussed in the literature in terms of relational financing. Are the banks in SSA "real partners accompanying the firm in its production activity?" (Chekili \& Saidane, 1995). This question seems to us opportune to reconsider in the sense that without a real bank-enterprise partnership relationship characterized by a commitment to the life of the company, there can be no pro-performance or even pro-growth credit allocation. This is, for example, the Hausbank principle defended in Germany. Otherwise, firms would face a credit rationing (Stiglitz \& Weil, 1981) which would then reduce performance.

The aim of this paper is to highlight the impact of bank financing on firms performance, from a relational financing perspective. The underlying assumption is that bank loans contribute positively to performance. The performance criterion used here is sales revenue. The analysis is based on a comparative approach between Cameroon and Senegal, which represent two flagship countries in the franc zones of Central and West Africa. In particular, it is based on primary data not used in previous investigations carried out in these countries. The rest of the paper is organized as follows: Section 2 presents estimation method and a data description. Section 3 is devoted to the presentation and discussion of the results. The policy implications of the results are provided at the Section 4 which concludes the paper.

\section{Methodology}

In this section, we present the analysis model that derives its theoretical basis from the microeconomic behavior of the producer, where the objective is to maximize profit. The firm performance equation is modeled and expresses a simplified relationship between a performance indicator and the resources mobilized.

\subsection{Model Specification}

The relationship between bank loans and firm performance is highlighted by the following standard model:

$$
y=\alpha_{0}+\alpha_{1} \text { credit }+X^{\prime} \beta+\varepsilon
$$

This equation defines a linear relationship between the performance indicator $y$, the interest variable (credit) and the vector of control variables $X ; \varepsilon$ represents the classic error term.

In this model, performance is assessed in terms of economic efficiency and is therefore approached by sales revenue. This is the economic version of the concept ${ }^{2}$ often used in empirical work, notwithstanding the diversity of definitions and the multiplicity of evaluation criteria (Djimasra et al., 2013; Sabarwal \& Terrell, 2009; Gauzente, 2000; Robichaud \& McGraw, 1997). Sales seem to be the key criterion for assessing performance within companies. As a source of income distribution, it sets the trend for the evolution of the activity. This is why managers themselves evaluate their performance in terms of sales growth (Janssen, 2004). The sales and profit objective thus underlies the focus on this indicator, which otherwise provides information on the value produced. In this sense, sales revenue is the expression of the value created and sold by the firm.

Apply and access to bank financing is expected to contribute more to improving sales, according to equation (1), taking into account the operation and/or investment covered. However, on the other hand, it is not meaningless to consider that only successful companies, in terms of the highest sales, are more likely to obtain a loan from financial institutions. This raises a problem of endogeneity, which is therefore anticipated through the double causality. In the absence of an estimation by instrumental variables (Note 3), the robustness of the model is ensured by using the approach adopted by Bardasi et al. (2011): we introduce past sales as one of the control variables. Therefore, the coefficient $\alpha_{1}$ in equation (1) denotes the effect of bank credit on current sales conditional on its past value. This coefficient can then be interpreted as the impact of bank credit on the growth of sales revenue (Note 4).

In order to present the results in terms of elasticity and to facilitate their interpretation, the variables $(y$, credit) are transformed into the logarithmic form. The model to be estimated is finally specified in the following form:

$$
y=\alpha_{0}+\alpha_{1} \text { credit }+\alpha_{2} y_{-1}+X^{\prime} \beta+\varepsilon
$$

The other control variables are distributed among the human capital of the manager and the characteristics of the 
firm, on the one hand, and the sector of activity considered, on the other hand.

The human capital of the manager is approximated by experience and technical training related to business activity. An experienced manager is more likely to be proactive in response to market conditions and reduce uncertainty factors through improved market knowledge. Previously, or even on an ongoing basis, the training followed by the manager governs his competence and establishes in some way his knowledge of the market.

Age and size (number of employees) are also the dimensions covered by the specific characteristics of the firm. The firm age is an indicator of survival that reflects the accumulated knowledge or skills. The more company is established over time, the more experience it acquires, builds partnerships and ensures its market share. Also, qualified and motivated workers should contribute to the overall performance of the firm. In addition to these company resources and skills, positioning in a sector of activity can provide a comparative advantage and influence productive dynamic. There is no reason to assume that the performance of enterprises is similar from one sector to another.

\subsection{Data}

The data used come from the survey on "Determinants of firms performance in French-speaking sub-Saharan Africa: the cases of Cameroon, Ivory Cost and Senegal." This survey is part of a vast research program aimed at analyzing the impact of social norms, ICTs and managerial skills on firms performance. Funded by the International Development Research Centre (IDRC), it was attended by three research centers from the three targeted flagship countries in the area.

The field survey took place over the same period in each of the three countries and is spread over November 2013-November 2014. Using questionnaires and similar sampling techniques, the firm-level data collected yield to cross-country comparisons. Sampling is carried out from the national registry of enterprises or the enterprises census database maintained by the national statistical institutes (NSIs).

A stratified sampling design is used in combination with the cut-off method for sample selection. In each country, the composition of the sample in terms of representativeness by industry is determined using sales as a criterion. The sampling methodology ensures that companies are representative by sector of activity (mainly manufacturing and service sectors). The sample selected is also representative according to the firm size: micro-enterprises, small enterprises, medium-sized enterprises and large enterprises. These include both private and public companies.

The data collected allows the identification of firms that received bank financing in fiscal year 2012. For each firm, they also provide information on loan applications during the two previous years and the sources of financing for the activity. However, some credit-related characteristics such as interest rate and loan maturities are not collected in this survey.

In view of the investigation to be carried out and the robustness of the econometric results, some restrictions are applied to the data:

- First of all, only formal private companies are included in the analysis (Note 5): public utilities are therefore excluded - as well as the informal sector. This exclusion is due to differences in the objectives pursued by the market sector (private sector) which is more inclined towards profit maximization (Bozec, 2004; Picard, 1998).

- In order to control for outliers, firms with a sale below the first percentile or above the last percentile are then excluded (Note 6).

For our comparative analysis, the initial dataset consists of 197 firm-level observations in the case of Cameroon and 278 observations in the case of Senegal (Note 7). Table A1 in the appendix provide some basic firm characteristics in the sample by country and by access or not to bank financing (Note 8).

\section{Results and Discussion}

In this section, we discuss the estimation results of the analysis model. Before moving on to the results and discussion, we carry out an analysis of variance to test whether or not access to credit is discriminatory.

\subsection{Analysis of Variance}

Table 1 below highlights firms' access to bank credit. Compared to Senegal, it shows that the rate of access to credit is higher in Cameroon. Nearly half of the private sector firms surveyed in Cameroon received financing in fiscal year 2012. This suggests that a partnership relationship is possible between the banks and the companies seeking financing. This partnership is all the more important because the existence of close relationship between 
borrowers and banks is an appropriate means of limiting credit rationing situations (Petersen \& Rajan, 1994). However, this is not the case in Senegal, where less than a third of the firms in the sample benefited from bank loans. It should also be noted that the business environment remains marked, not only in Senegal but also in Cameroon, by a constraint on access to finance (Figure A1, appendix). It is the top business environment obstacle to their day-to-day operations noted by managers in Senegal.

Table 1. Firm's access to bank financing

\begin{tabular}{lcccc}
\hline & \multicolumn{2}{c}{ CAMEROON } & \multicolumn{2}{c}{ SENEGAL } \\
\cline { 2 - 5 } Access to bank financing & Obs. & $\%$ & Obs. & $\%$ \\
\hline Yes & 81 & 48.21 & 81 & 29.14 \\
No & 87 & 51.79 & 197 & 70.86 \\
Total & 168 & 100 & 278 & 100 \\
\hline
\end{tabular}

At the same time, the dispatching of the enterprises population into two groups leads to test if access to credit leads to a difference in performance. The idea is to compare the group of credit recipients with the group of non-recipients using an analysis of variance (ANOVA). We then use the model (3) which qualitatively describes the effect of access to credit on the sales for the year:

$$
y_{i k}=a+c_{k}+u_{i k}
$$

Where

$y_{i k}$ is the logarithm of the sales revenue of firm $i$ belonging to group $k(k=1,2)$;

$c_{k}$ refers to the effect of access to credit ( 1 if yes and 0 if no) on $y_{i k}$;

The constant $a$ represents the common effect to all firms and $u_{i k}$ the disruptive effect.

The estimation of the parameters of this model leads to the following results (Table 2): in Senegal no detectable difference was found between the two groups (recipients and non- recipients of credit). In Cameroon, on the other hand, access to credit seems to have an influence on sales for the period. Intuitively, bank financing is expected to have a beneficial effect in that firms that have obtained bank loans are expected to have higher sales than those that do not. The ANOVA in both cases is, however, mixed and does not yet allow for a policy discussion (as to the effect of the credit on the performance of recipient firms). It is clear that the level of sales achieved by these firms may not be the only fact of having benefited from the credits.

Table 2. Results of the analysis of variance

\begin{tabular}{lcc}
\hline VARIABLES & CAMEROON & SENEGAL \\
\hline Access to credit & $0.978^{* * * *}$ & 0.345 \\
& $(0.374)$ & $(0.333)$ \\
Constant & $20.489 * * *$ & $19.233 * * *$ \\
& $(0.262)$ & $(0.18)$ \\
Observations & 157 & 278 \\
R-square & 0.042 & 0.004 \\
\hline
\end{tabular}

Note. Standard errors in parentheses. $* * * \mathrm{p}<0.01, * * \mathrm{p}<0.05, * \mathrm{p}<0.1$.

Since statistical analysis is insufficient, we carry out econometric analysis to assess the proven effect of bank financing on the performance of recipient firms. As we are interested in the impact of credit on firms performance, only the recipient firms will be concerned by the econometric estimate.

\subsection{Impact of Credit on Firms Performance}

The estimation results for our basic model (model 2) that evaluates the impact of bank financing on the growth of sales revenue are presented in Table 3. Using OLS regressions, the estimate is made step by step, including sequentially the characteristics of the firm and then those of the manager.

In view of the results, it appears that bank financing contributes negatively to the performance of firms in both Cameroon and Senegal. In the estimates (2) and (3), the interest variable (Credit) has a significantly negative coefficient. When the credit volume increases by 1 per cent, the sales growth decreases by 0.04 per cent. Consequently an inverse relationship is established between the volume of bank debt and sales revenue. As a result, the bank debts negotiated by firms are unfavorable to their performance. Thus they appear to be an obstacle to the development and emergence of businesses. This seemingly counterintuitive result is not the first of its kind. The authors, such as Tioumagneng (2011) and Wanda (2001), found similar results regarding the 
inverse relationship between bank debt and firms performance. This then leads to rejecting the hypothesis that bank loans in Cameroon and Senegal favorably affect performance of firms.

In this model, the fact that Credit negatively explains the growth of sales revenue obviously runs counter to what can be called the "credit productivity theory" defended by Schumpeter (1911). If for this author, only the credit created and made available to enterprises is a productive power for them or a driving force behind their performance, in the present case of Cameroon and Senegal, bank financing does not produce the expected effect: rather, there seems to be a sort of "neutrality" of bank loans in the sense of Modigliani and Miller's (1958) model. The supposed virtue of indebtedness is contrasted here: the loans offered to firms are growth-reducing and denote non-relational financing. Indeed, if access to credit is a major constraint noted in SSA, the financing then contracted is hampered by the lack of a cooperative framework. This means, in other words, that the allocation of credit is not accompanied by a partnership relationship, which requires support for productive activity and not the adoption of purely mercantile or transactional behavior on the part of banks (David et al., 2008).

As a result, this negative influence of bank loans on firms performance does indeed relate to an underlying phenomenon in existing analyses. The credit rationing thesis is therefore being used - was it commonly noted in the literature on bank financing (Stiglitz \& Weiss, 1981; Ayed \& Zouari, 2014; Seck, 2014). It should be recalled that many of these firms consider access to bank financing as the most important obstacle to doing business: 38.6 per cent of enterprises in Senegal, a percentage well above the sub-Saharan average (Figure A1, appendix). The difficulty for the firm to obtain bank credit, which results, among other things, in obtaining an amount less than the demand, crowds out the efficiency of the financing in terms of supporting the activity. In particular, the low level of bank debt cannot, quite rightly, produce a significant improvement in productivity and growth - as long as it is insufficient for modernization and innovation.

The credit rationing thesis favored in this research reflects the reluctance of banks to offer financing to firms. This overall behavior of the banking sector in the Franc Zones of Central and West Africa (reported in the work of authors such as Kauffmann, 2005; Lefilleur, 2008; Tioumagneng, 2011) is indicative of the difficult context in which productive units operate in their development strategies. Firms that are rationed in the credit market face a significant obstacle to their growth and further development.

The expected performance of the firm is therefore compromised in the sense that the firm's productive investment is financially constrained. In addition, the cost of bank financing and the high demand for collateral, which are also characteristic of the business environment, may be factors that reduce the efficiency of the loans offered to firms. They partly reflect the difficulty of access to credit and act as a brake on activity in the sense that firms tend to finance long-term investments (costlier) with short-term loans (Djimasra et al., 2013).

Table 3. Results of econometric estimation

\begin{tabular}{lcccccc}
\hline & \multicolumn{3}{c}{ CAMEROON } & \multicolumn{3}{c}{ SENEGAL } \\
\cline { 2 - 6 } VARIABLES & $(1)$ & $(2)$ & $(3)$ & $(1)$ & $(2)$ & $(3)$ \\
\hline Credit & -0.023 & $-0.042^{* *}$ & $-0.037^{*}$ & -0.020 & $-0.037^{* *}$ & $-0.036^{*}$ \\
& $(0.020)$ & $(0.019)$ & $(0.021)$ & $(0.015)$ & $(0.015)$ & $(0.021)$ \\
Service sector & & 0.022 & 0.021 & & $-0.103^{*}$ & $-0.115^{*}$ \\
& & $(0.082)$ & $(0.079)$ & & $(0.061)$ & $(0.065)$ \\
Firm size & & -0.0001 & $-0.0001^{* *}$ & & $0.0001^{*}$ & $0.0001^{* * *}$ \\
& & $(0.000)$ & $(0.000)$ & & $(0.000)$ & $(0.000)$ \\
Firm age & & -0.002 & $-0.004^{*}$ & & 0.002 & 0.004 \\
& & $(0.003)$ & $(0.002)$ & & $(0.004)$ & $(0.004)$ \\
Manager's experience & & & & -0.001 \\
& & & & & $(0.002)$ \\
Has completed technical & & & & & -0.079 \\
training & & & $0.001)$ & & $(0.058)$ \\
y-1 & & 0.095 & & -0.009 \\
Constant & 0.013 & 0.018 & 0.023 & 0.007 & -0.008 & -0.009 \\
& $(0.022)$ & $(0.021)$ & $(0.023)$ & $(0.014)$ & $(0.014)$ & $(0.021)$ \\
Observations & 0.085 & 0.286 & 0.080 & 0.276 & $0.853^{* * *}$ & $0.910^{* *}$ \\
R-square & $(0.409)$ & $(0.360)$ & $(0.393)$ & $(0.250)$ & $(0.306)$ & $(0.453)$ \\
\hline
\end{tabular}

Note. The estimate (1) first includes the volume of bank credit and the control variable past sales. The estimate (2) then includes the sector of activity and the firm's characteristics. The estimate (3) also adds the manager's skills. The reported estimate coefficient of $\mathrm{y}_{-1}$ is the one corresponding to $\left(\alpha_{2}-1\right)$. Robust standard errors in parentheses. *** $\mathrm{p}<0.01, * * \mathrm{p}<0.05, * \mathrm{p}<0.1$. 
Therefore it seems that bank credit is not yet having the expected effect on activity in the Cameroonian and Senegalese private sector. The same applies to the manager's experience and technical training related to business activity. On the other hand, the firm age and the fact that it belongs to the service sector negatively explain the growth of sales revenue in Cameroon and Senegal respectively. The firms performance in Cameroon should benefit more from belonging to a network (professional, friends or others) than simply from the criterion of age or seniority. The highly increased competitive practices of the informal sector in Senegal may justify the loss of performance of firms operating in the service sector compared to those in the manufacturing sector.

\section{Conclusion}

The interest aroused in recent years by the researchers and the support of governments in SSA for improving access of firms to bank credit has led us to examine the efficiency of the financing contracted. As much as a consensus prevails around the driving role played by the private sector in terms of job and wealth creation, without adequate support from banks, companies cannot significantly prosper and set in motion a better productive dynamic of the economy. Beyond the obvious, it is important to question the contribution of the supply of financing to the performance of firms. A close bank-enterprise relationship is highly indicative in the context of underdeveloped countries in order to remove obstacles to access to credit and meet the growth challenge. Financing, it seems, is a lever for the growth of businesses and entrepreneurs in Africa rely on the supply of bank credit to support their activity, improve productivity and generally stimulate growth.

The aim of this paper was to provide evidence on the impact of bank credit on firms performance in Cameroon and Senegal. To do this, a linear regression model is estimated; model in which performance is similar to sales growth. The results of the estimates show that the financing that firms obtain from banks has a negative impact on their performance. The investigation thus highlights the fact that the credits offered by the banking sector to companies operating in Cameroon and Senegal do not yet contribute to their performance. The explanatory cause of these unfavorable results is to be considered in the credit rationing thesis, especially since access to financing is a major constraint for businesses. The reasoning is in line with the fact that a rationed supply of financing severely limits the effective implementation of investment or operational activities. The absence of relational behavior in the credit market supports this explanation. Without a genuine bank-enterprise relationship, the expected effect of bank loans on firms performance cannot be positive.

These results argue for the establishment of a close bank-enterprise relationship in the common pursuit of promoting economic growth. Building or strengthening such relationship is beneficial to both parties. For the firm, it should make it possible to guard against a state of rationing and guarantee the availability of credit. The seemingly counterintuitive results of the regressions do not in themselves challenge the virtues of bank financing. Rather, they suggest that rationed credit cannot adequately meet operating and investment needs. At the bank, this partnership relationship would make it possible to minimize information asymmetries and to ensure its capital gains through the renewed economic upturn.

\section{References}

Aryeetey, E. (1998). Informal finance for private sector development in Africa. Economic Research Papers, 41. Retrieved from https://www.afdb.org/fileadmin/uploads/afdb/Documents/Publications/00157616-FR-ERP-41.PDF

Ayed, W. H. B., \& Zouari, S. G. (2014). Contraintes financières et innovation dans les PME: une étude économétrique dans le contexte tunisien. Revue Internationale P.M.E., 27(2), 63-94. https://doi.org/10.7202/1026068ar

Bardasi, E., Sabarwal, S., \& Terrel, K. (2011). How do female entrepreneurs perform? Evidence from three developing regions. Small Business Economics, 37(4), 417-441. https://doi.org/10.1007/s11187-011-9374-z

Becchetti, L., \& Trovato, G. (2002). The determinants of growth for small and medium sized firms: The role of the availability of external finance. Small Business Economics, 19(4), 291-306. https://doi.org/10.1023/A:1019678429111

Belouard, A. N., \& Seder, S. (2009). Structure du capital et de la performance des PME algériennes. Revue Économie et Management, 2009(9), 121-132. Retrieved from http://fseg2.univ-tlemcen.dz/larevue09/Ali\%20Nabil\%20BELOUARD+samir\%20seder.pdf

Bozec, R. (2004). L'analyse comparative de la performance entre les entreprises publiques et les entreprises privées: Le problème de mesure et son impact sur les résultats. L'Actualité économique, 80(4), 619-654. https://doi.org/10.7202/012130ar 
Chekili, S., \& Saidane, D. (1995). La dimension bancaire et financière: Facteur d'efficacité de l'entreprise en Afrique. In J. L. Eurotext (Ed.), Les facteurs de performance de l'entreprise (pp. 81-95). AUPELF-UREF.

David, P., O'Brien, J. P., \& Yoshikawa, T. (2008). The implications of debt heterogeneity for R\&D investment and firm performance. Academy of Management Journal, 51(1), 165-181. https://doi.org/10.5465/amj.2008.30772877

Djimasra, N., Gadom, D. G., Abba, D., \& Djam'Angai, L. (2013). Crédit bancaire et performance des petites et moyennes entreprises tchadiennes à l'ère pétrolière. Rapport de recherche $d u F R$-CIEF, 74/13. Retrieved from http://www.trustafrica.org/en/publications-trust/icbe-research-reports?download=345:credit-bancaire-et-perf ormance-des-petites-et-moyennes-entreprises-tchadiennes-a-l-ere-petroliere

Dohou, A., \& Berland, N. (2007). Mesure de la performance globale des entreprises. Retrieved from https://halshs.archives-ouvertes.fr/halshs-00544875

Gauzente, C. (2000). Mesurer la performance des entreprises en l'absence d'indicateurs objectifs: Quelle validité? Analyse de la pertinence de certains indicateurs. Finance Contrôle Stratégie, 3(2), 145-165.

Germain, C., \& Trebucq, S. (2004). La performance globale de l'entreprise et son pilotage: Quelques réflexions. Au-delà de la RSE: la responsabilité globale, Semaine sociale Lamy, 1186, 35-41. Retrieved from https://hal.archives-ouvertes.fr/hal-00765165/

Janssen F. (2004). L'interchangeabilité des critères de conceptualisation de la croissance: étude empirique. IAG-LSM working papers, 04/118. Retrieved from http://hdl.handle.net/2078/18208

Jõeveer, K., Pissarides, F., \& Svejnar J. (2006). Bank Lending and Performance of Micro, Small and Medium Sized Enterprises (MSMEs): Evidence from Bulgaria, Georgia, Russia and Ukraine. Working paper. Retrieved https://www.cass.city.ac.uk/_data/assets/pdf_file/0008/78785/Joeveer20Pissarides20Svejnar.pdf

Kauffmann, C. (2005). Le financement des PME en Afrique. Repères, 7. https://doi.org/10.1787/20772602

Lefilleur, J. (2008). Comment améliorer l'accès au financement pour les PME d'Afrique subsaharienne? Afrique Contemporaine, 3(227), 153-174. https://doi.org/10.3917/afco.227.0153

Modigliani, F., \& Miller, M. (1958). The Cost of Capital, Corporation Finance and the Theory of Investment. American Economic Review, 48(3), 261-297. Retrieved from http://www.jstor.org/stable/1809766

Modigliani, F., \& Miller, M. (1963). Corporate Income Taxes and the Cost of Capital: A Correction. American Economic Review, 53(3), 433-443. Retrieved from http://www.jstor.org/stable/1809167

Myers, S., \& Majluf, N. (1984). Corporate financing and investment decisions, when firms have information that investors do not have. Journal of Financial Economics, 13(2), 187-221. https://doi.org/10.1016/0304-405X(84)90023-0

Petersen, M. A., \& Rajan, R. (1997). Trade Credit: Theories and Evidence. Review of Financial Studies, 10(3), 661-691. https://doi.org/10.3386/w5602

Picard, P. (1998). Eléments de microéconomie: 1.Théorie et applications (5th éd.). Paris : Montchrestien.

Robichaud, Y., \& McGraw, E. (1997). Etude des facteurs explicatifs de la performance des PME appartenant à des femmes. Revue du Nouvel-Ontario, 21.

Sabarwal, S., \& Terrel, K. (2009). Access to credit and performance of female entrepreneurs in Latin America (Summary). Frontiers of Entrepreneurship Research, 29(18/6). Retrieved from http://digitalknowledge.babson.edu/fer/vol29/iss18/6

Salgado, M. (2013). La performance: Une dimension fondamentale pour l'évaluation des entreprises et des organisations. Document de travail. Retrieved from https://hal.archives-ouvertes.fr/hal-00842219

Schumpeter, J. A. (1911/1935). Théorie de l'évolution économique. Recherches sur le profit, le crédit l'intérêt et le cycle de la conjoncture (J-J. Anstett, Trans). Paris.

Schumpeter, J. A. (1939). Business cycles: A theorecal, historical and statistical analysis of the capitalist process. New York and London: McGraw-Hill, 1964.

Seck, M. A. (2014). Accès au Financement Bancaire des Petites et Moyennes Entreprises au Sénégal. Working paper.

Retrieved

from https://docplayer.fr/1142695-Acces-au-financement-bancaire-des-petites-et-moyennes-entreprises-au-seneg 
al.html

Silivestru, D. R. (2012). Bank loans and small firm financing in Romania. Annales Universitatis Apulensis Series Oeconomica, 14(1).

Stiglitz, J. E., \& Weiss, A. (1981). Credit rationing in markets with imperfect information. American Economic Review, 71(3), 393-410. Retrieved from www.jstor.org/stable/1802787

Stiglitz, J. E., \& Weiss, A. (1987). Credit rationing: Reply. American Economic Review, 77(1), $228-231$. Retrieved from http://www.jstor.org/stable/1806744

Tioumagneng, A. T. (2011). Maturité des crédits bancaires et performance des entreprises : cas du Cameroun. Mondes en Développement, 153. https://doi.org/10.3917/med.153.0071

Wanda, R. (2001). Structure financière et performance des entreprises dans un contexte sans marché financier : le cas du Cameroun. Working paper. Retrieved from https://docplayer.fr/2178904-Structure-financiere-et-performance-des-entreprises-dans-un-contexte-sans-ma rche-financier-le-cas-du-cameroun.html

\section{Notes}

Note 1. The arguments put forward in the literature on banks' reluctance to grant credit relate to information asymmetries, insufficient collateral and the high default risk attached to SMEs. On the continent, banks remain the main providers of liquidity to companies, partly because of a weakly developed financial market.

Note 2. This version is due to the fundamental aims of the economic prosperity of any business (Germain and Trebucq, 2004; Dohou and Berland, 2007).

Note 3. The impossibility of having valid instruments in our database forces us to overlook an estimate by instrumental variables and to use another approach.

Note 4 . The model could still be rewritten in the form of $y-y_{-1}=\alpha_{0}+\alpha_{1}$ credit $+\left(\alpha_{2}-1\right) y_{-1}+X^{\prime} \beta+$ $\varepsilon$; the difference in logarithm $y-y_{-1}$ defining a growth rate.

Note 5. Is considered to be a formal company, a company that is administratively registered and keeps formal accounts. Only the private sector is considered here because, as Pestieau and Gathon (1996) point out, value creation cannot be understood as a search for financial profit by the public sector (cited by Salgado, 2013).

Note 6. In the particular case of Senegal, an observation not following the overall movement of the distribution was also dropped.

Note 7. Ivory Cost is withdrawn from the comparative analysis envisaged because of the lack of observations on the variable of interest, i.e. the volume of bank credit (21 observations in total).

Note 8. In particular, we note in table 4 (appendix) that the manager's degree of experience is a factor that favors access to credit. Combined with the age of the manager, experience can sustain the effect of credit on business performance through different channels.

Note 9. See World Bank enterprise surveys, Cameroon, country profile 2009 or Senegal, country profile 2014 (available at www.enterprisesurveys.org). 


\section{Appendix}

\section{Firms characteristics and business environment}

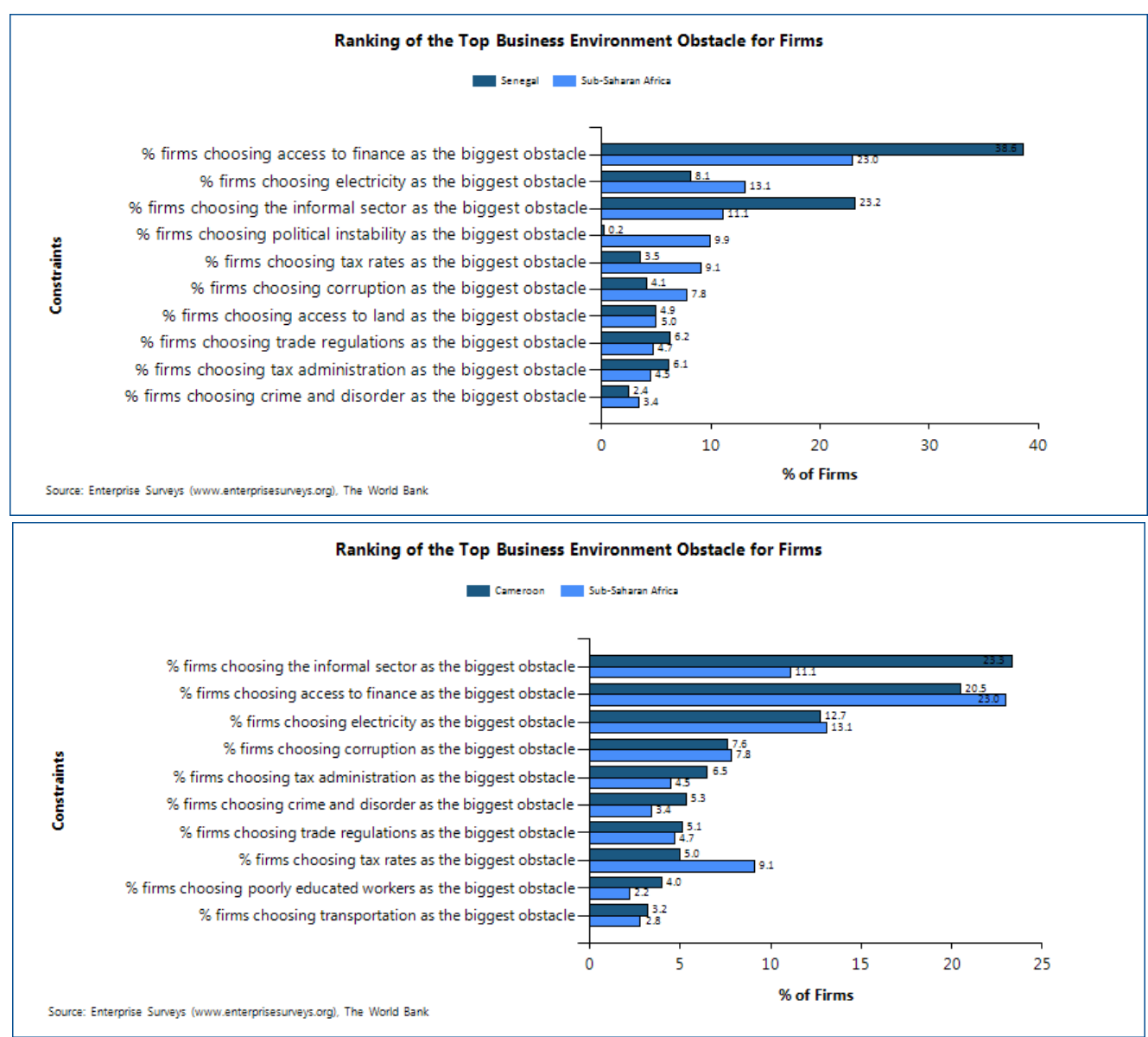

Figure A1. Top 10 business environment obstacles

Note. The observations correspond to firms' choices regarding the most important obstacle from a list of 15 elements that characterize the business environment. They are compared to the regional average and ranked in descending order of the responses given in Senegal and Cameroon (See http://www.enterprisesurveys.org/graphing-tool).

Table A1. Summary statistics

\begin{tabular}{lcccccc}
\hline & \multicolumn{3}{c}{ CAMEROON } & \multicolumn{3}{c}{ SENEGAL } \\
\cline { 2 - 7 } & Recipients & Non- Recipients & Total & Recipients & Non- Recipients & Total \\
\hline Sales (in million CFA Franc) & $17406.31^{\text {Sig }}$ & 5736.05 & 13243.73 & 4274.15 & 6309.95 & 5716.79 \\
Value Added (in million CFA Franc) & 5489.56 & 2119.36 & 3597.76 & 608.14 & 1118.96 & 970.13 \\
Firm age (years) & 18.51 & 18.45 & 19.25 & 12.71 & 15.20 & 14.46 \\
Nomber of employees & 246.75 & 114.43 & 176.76 & 83.09 & 50.28 & 59.84 \\
Service sector (\%) & 62.96 & 56.32 & 61.42 & $61.73^{\text {Sig }}$ & 72.59 & 69.42 \\
Manager's age (years) & 49.93 & 47.17 & 47.90 & 49.41 & 48.84 & 49 \\
Manager's experience (years) & $20.96^{\text {Sig }}$ & 14.81 & 17.40 & $22.17^{\text {Sig }}$ & 19.18 & 20.05 \\
Has received technical training (\%) & 71.60 & 77.01 & 73.10 & 64.20 & 67.01 & 66.19 \\
Holder of a higher diploma (\%) & 76.92 & 71.76 & 73.54 & 62.50 & 71.05 & 68.52 \\
Female owner or entrepreneur (\%) & 12.35 & 10.34 & 10.66 & 12.35 & 13.20 & 12.95 \\
\hline
\end{tabular}

\section{Copyrights}

Copyright for this article is retained by the author(s), with first publication rights granted to the journal.

This is an open-access article distributed under the terms and conditions of the Creative Commons Attribution license (http://creativecommons.org/licenses/by/4.0/). 